\title{
Sphingosine 1-Phosphate (S1P) Signaling Is Required for Maintenance of Hair Cells Mainly via Activation of $\mathrm{S}_{1} \mathrm{P}_{2}$
}

\author{
Deron R. Herr, ${ }^{1}$ Nicolas Grillet, ${ }^{2}$ Martin Schwander, ${ }^{2}$ Richard Rivera, ${ }^{1}$ Ulrich Müller, ${ }^{2}$ and Jerold Chun ${ }^{1}$ \\ ${ }^{1}$ Department of Molecular Biology, Helen L. Dorris Institute for Neurological and Psychiatric Disorders, and ${ }^{2}$ Department of Cell Biology, Institute for \\ Childhood and Neglected Disease, The Scripps Research Institute, La Jolla, California 92037
}

\begin{abstract}
Hearing requires the transduction of vibrational forces by specialized epithelial cells in the cochlea known as hair cells. The human ear contains a finite number of terminally differentiated hair cells that, once lost by noise-induced damage or toxic insult, can never be regenerated. We report here that sphingosine 1-phosphate $(\mathrm{S} 1 \mathrm{P})$ signaling, mainly via activation of its cognate receptor $\mathrm{S}_{2} \mathrm{P}_{2}$, is required for the maintenance of vestibular and cochlear hair cells in vivo. Two S1P receptors, $\mathrm{S}_{1} \mathrm{P}_{2}$ and $\mathrm{S1P}_{3}$, were found to be expressed in the cochlea by reverse transcription-PCR and in situ hybridization. Mice that are null for both these receptors uniformly display progressive cochlear and vestibular defects with hair cell loss, resulting in complete deafness by 4 weeks of age and, with complete penetrance, balance defects of increasing severity. This study reveals the previously unknown role of S1P signaling in the maintenance of cochlear and vestibular integrity and suggests a means for therapeutic intervention in degenerative hearing loss.
\end{abstract}

Key words: GPCR; hair cell; hearing loss; cochlea; vestibular; knock-out mice

\section{Introduction}

Lysophospholipids are an important class of extracellular signaling molecules that are involved in many aspects of normal mammalian physiology and pathophysiology. Sphingosine 1-phosphate (S1P) is a major lysophospholipid species that elicits effects in organisms as diverse as yeast, Dictyostelium, Drosophila, zebrafish, rodents, and humans (Saba et al., 1997; Kupperman et al., 2000; Li et al., 2001; Yang et al., 2002; Herr et al., 2003; Spiegel and Milstien, 2003). In vertebrates these responses are thought to be mediated predominantly by a family of five G-proteincoupled receptors (GPCRs) known as $\mathrm{S}_{1-5}$ (Anliker and Chun, 2004; Ishii et al., 2004; Saba and Hla, 2004). These receptors influence a range of biological functions including vascular development, angiogenesis, cancer growth, immunity, and cardiovascular and nervous system function (Gardell et al., 2006), but previously they have not been reported to be important for cochlear or vestibular function. $\mathrm{S}_{1} \mathrm{P}_{1-3}$ are expressed widely in the developing and adult organism. Functional studies have been facilitated greatly by the generation of receptor-null mice. Although $s 1 p_{1}^{-1-}$ mice die embryonically from blood vessel malformation (Liu et al., 2000), $s 1 p_{2}{ }^{-1-}$ and $s 1 p_{3}{ }^{-1-}$ single-null mice show relatively mild phenotypes with no gross anatomical or behavioral abnormalities (Ishii et al., 2000, 2001; MacLennan et al., 2001).

To assess the functional redundancy of $\mathrm{S}_{1} \mathrm{P}_{2}$ and $\mathrm{S}_{1} \mathrm{P}_{3}$ signal-

Received Sept. 28, 2006; revised Jan. 5, 2007; accepted Jan. 6, 2007.

This work was supported by National Institutes of Health Grants MH051699, MH01723, NS048478, and HD050685 (J.C.). We thank Christine Paczkowski, Danielle Letourneau, and Suzanne Peterson for a critical review of this manuscript and Anna Sczaniecka for expert technical assistance.

Correspondence should be addressed to Jerold Chun, Department of Molecular Biology, The Scripps Research Institute, 10550 North Torrey Pines Road, La Jolla, CA 92037. E-mail: jchun@scripps.edu.

D01:10.1523/JNEUROSCI.4245-06.2007

Copyright $\odot 2007$ Society for Neuroscience $\quad$ 0270-6474/07/271474-05\$15.00/0 ing, we generated $s 1 p_{2} / s 1 p_{3}$ double-null mice (Ishii et al., 2002). Whereas $s 1 p 3$ single-null mice displayed no readily detectable physiological defects despite a measurable reduction in S1P responsiveness of fibroblasts (Ishii et al., 2001), double-null mice were characterized by subtle but consistent phenotypes. There was a marked reduction in litter size and an increase in perinatal lethality among $s 1 p_{2}^{-1-} / s 1 p_{3}{ }^{-1-}$ pups. Additional analyses identified postural defects that led us to examine vestibular function. Here we report significant and progressive degeneration of auditory and vestibular organs that result in complete deafness and balance defects in $s 1 p_{2}{ }^{-1-}$ and $s 1 p_{2}{ }^{-1-} / s 1 p_{3}{ }^{-1-}$ mice. Our data identify a novel function for receptor-mediated S1P signaling in inner ear hair cell maintenance and suggest that a loss of S1P signaling may be a factor in degenerative hearing loss in humans.

\section{Materials and Methods}

Animal husbandry

Mice were housed in ventilated cages in the vivarium at The Scripps Research Institute. $s 1 p_{2} / s 1 p_{3}$ double-null mice were generated and maintained as described (Ishii et al., 2002) in a 129/SvJ, C57BL/6N mixed background.

\section{Behavioral assays}

Forced swim. Mice were placed in a 1 or $2 \mathrm{~L}$ beaker three-fourths full of warm $\left(30-32^{\circ} \mathrm{C}\right)$ tap water and observed for a 1 min test period. Mice that sank to the bottom of the beaker or were unable to keep their nose above the surface of the water for a period of $5 \mathrm{~s}$ were rescued and scored as a swim failure. In each group 5-17 mice were tested at each time point.

Open field. Mice were allowed to ambulate freely in an open field chamber for a $30 \mathrm{~min}$ test period. The chamber has infrared sensor beams placed at a height of $75 \mathrm{~mm}$ that are broken when the mice rear on their hind legs. Rears per minute reflect the number of beam breaks occurring in the center of the chamber during the time spent in this area; $n=9$ mice aged 12-14 weeks in each group.

Contact righting. Subjects were placed in a standard $150 \mathrm{~mm}$ Petri dish 
so that each mouse was in contact with a flat surface both dorsally and ventrally. When the dish was inverted, wild-type mice sensed that they were upside-down and immediately righted themselves. Mice with vestibular lesions, however, became disoriented and often experienced a delay in righting behavior.

Acoustic startle response. The acoustic startle test was performed by using a startle response system (SR-LAB apparatus, San Diego Instruments, San Diego, CA) as described previously (Risbrough et al., 2003). Subjects were restrained inside a Plexiglas tube with a $40 \mathrm{~mm}$ inner diameter in a ventilated, darkened chamber and then were exposed to clicks of defined, variable decibels at random intervals. Response was measured in arbitrary units with a force transducer and accompanying SR-LAB software. Responses were discarded when preceded by detectable motion in the restraint chamber before click stimulus. Then 7-15 individual mice, $4-12$ weeks of age, were analyzed in each group. Wildtype or heterozygous littermate controls were included with all knockout mice at the time of testing.

\section{Reverse transcription-PCR}

RNA was purified from the indicated tissues with a Qiagen RNeasy kit (catalog number 74104, Hilden, Germany) and was reverse transcribed with Superscript II (catalog number 18064-022, Invitrogen, Carlsbad, CA). Quantitative real-time reverse transcription-PCR (qRT-PCR) was performed in the presence of SYBR Green (catalog number S4438, Sigma-Aldrich, St. Louis, MO) with the use of a Rotor-Gene 3000 (Corbett Research, Sydney, Australia). Copy number was determined for each receptor by comparing the cycle threshold to a standard curve of known target concentrations and then standardized to a reference gene $(\beta$ actin). Nonquantitative RT-PCR was performed as described (Lee et al., 2006).

\section{In situ hybridization}

Pups aged 0-4 d were killed by isoflurane inhalation and decapitated. Heads were bisected, fixed overnight in 4\% paraformaldehyde (PFA)/ PBS, and cryoprotected in 30\% sucrose. Cochleas from mice $>7 \mathrm{~d}$ old were treated similarly, with the addition of a decalcification step for $2 \mathrm{~d}$ in 5\% EDTA/4\% PFA/PBS before cryoprotection. All tissues then were embedded in Tissue-Tek OCT compound (catalog number 25608-930, VWR, West Chester, PA), sectioned to $12 \mu \mathrm{m}$, and hybridized with genespecific probes as described previously (Grillet et al., 2003). The open reading frames of mouse $\mathrm{S}_{2} \mathrm{P}_{2}$ and $\mathrm{S}_{1} \mathrm{P}_{3}$ cDNAs were subcloned into pBluescript SK (Stratagene, La Jolla, CA) and used as templates for RNA probe synthesis.

\section{Histology/immunohistochemistry}

Mice were killed by deep anesthesia with isoflurane inhalation and then perfused transcardially with $4 \%$ PFA. Whole inner ear structures and surrounding tissue were removed intact, fixed overnight in Bouin's fixative, dehydrated in ethanol, decalcified overnight in $4 \%$ hydrochloric acid $/ 4 \%$ formic acid, and neutralized in dilute ammonia. The tissues were embedded in paraffin, sectioned, and stained via routine techniques. Whole-mount surface preparation and staining of neonatal cochleas were performed as described previously (Senften et al., 2006).

\section{Results}

S1P receptors are expressed in the murine cochlea

Nonquantitative RT-PCR analysis identified the expression of three S1P receptor subtypes in the murine cochlea (Fig. 1A). To identify any developmentally relevant changes in the expression of these genes, we performed qRT-PCR (Fig. $1 B$ ). Notably, ${\mathrm{S} 1 \mathrm{P}_{2}}$ has a much higher level of expression when compared with $\mathrm{S}_{1} \mathrm{P}_{1}$ and $\mathrm{S}_{1} \mathrm{P}_{3}$ and is upregulated significantly at the later ages, with expression approximately sixfold greater at postnatal day 28 (P28) as compared with P0 ( $p=0.0039)$. In situ hybridization suggests that cochlear expression of $\mathrm{S}_{2} \mathrm{P}_{2}$ is localized exclusively inside the organ of Corti, primarily in the supporting cells, with a weak signal sporadically detected in the inner and outer sensory hair cells (Fig. 1C) (supplemental Fig. S1, available at www.
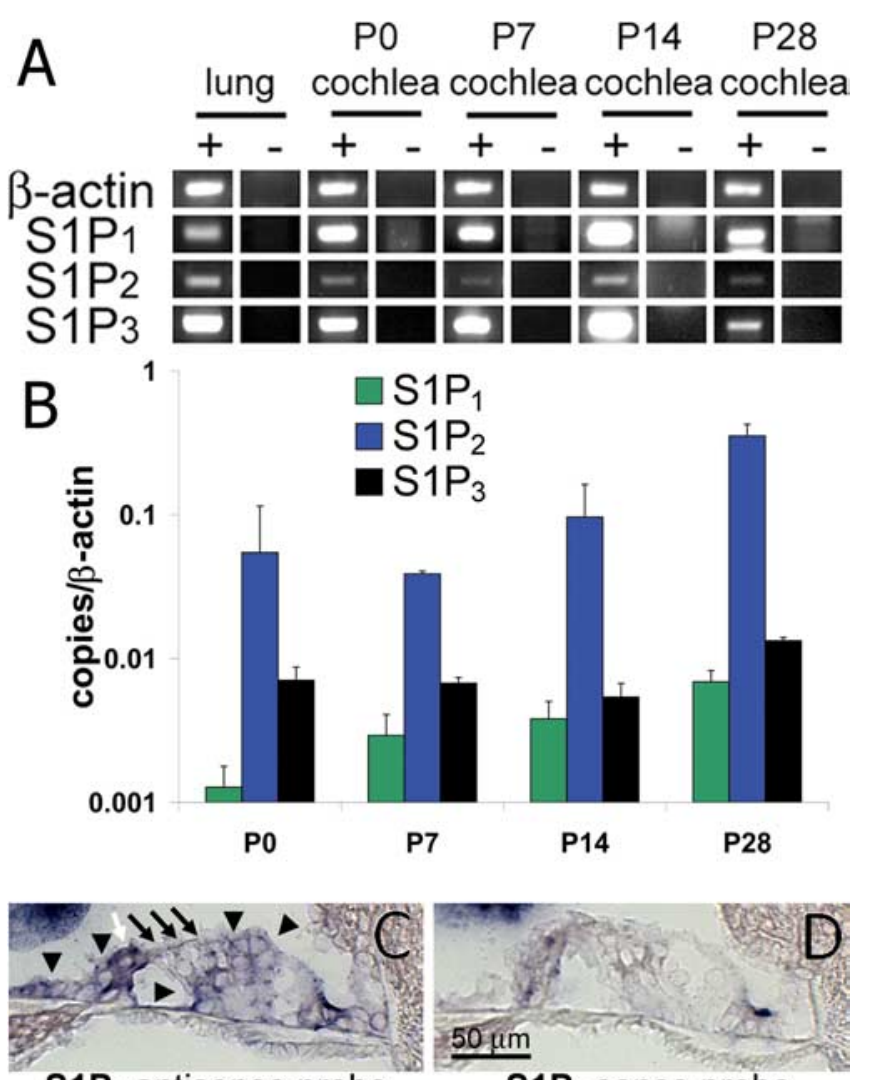

$\mathrm{S}_{1} \mathrm{P}_{2}$ antisense probe

$\mathbf{S}_{1} \mathbf{P}_{2}$ sense probe

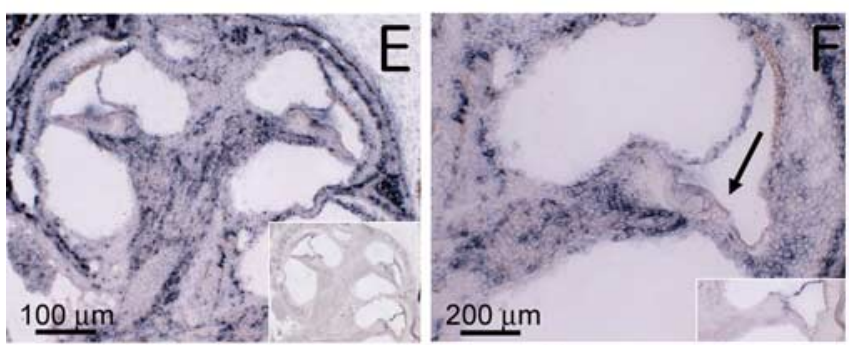

$\mathrm{S}_{1} \mathrm{P}_{3}$ antisense probe

Figure 1. S1P receptors are expressed in the cochlea. $A, R T-P C R$ analysis demonstrates that three high-affinity S1P receptors $\left(S_{1} P_{1-3}\right)$ are expressed in the murine cochlea from neonates into adulthood. $\beta$-Actin primers served as a CDNA loading control. The lung CDNA served as a positive control for the primers, because all three genes are known to be expressed there (Ishii et al., 2001). All CDNA samples ( + ) were run in parallel with a negative control template prepared without the addition of reverse transcriptase (-). B, qRT-PCR reveals the developmental dynamics of S1P receptor expression in the cochlea. Expression level is represented as copies of receptor mRNA per copy of $\beta$-actin mRNA. Values are averages of three individual mice at each time point. Error bars indicate SD. C, In situ hybridization of this P19 cochlea indicates that $\mathrm{S}_{\mathrm{P}}$ is expressed in the organ of Corti in the supporting cells (arrowheads), primarily those underlying the hair cells. There is little detectable signal in the hair cells (arrows), but it is observed occasionally as shown here (white arrow). $\boldsymbol{D}$, Sense-strand control demonstrating the specificity of the $\mathrm{S}_{2}$ probe. $E$, In situ hybridization of this $\mathrm{P} 4$ cochlea with an $\mathrm{S}_{1} \mathrm{P}_{3}$-specific antisense probe shows that $\mathrm{S}_{3} \mathrm{P}_{3}$ is expressed throughout the cochlea and spiral ganglia. Its pattern suggests expression in the vasculature and possibly the cochlear glia. $\boldsymbol{F}$, Highermagnification view emphasizing that little expression of $\mathrm{SPP}_{3}$ is observed inside the organ of Corti (arrow). Insets show sense-strand control probes in $\boldsymbol{E}$ and $\boldsymbol{F}$.

jneurosci.org as supplemental material). In contrast, $\mathrm{S}_{1} \mathrm{P}_{3}$ is expressed primarily outside the organ of Corti in a pattern that is consistent with the vasculature and possibly glial populations of the cochlea (Fig. 1E,F). 

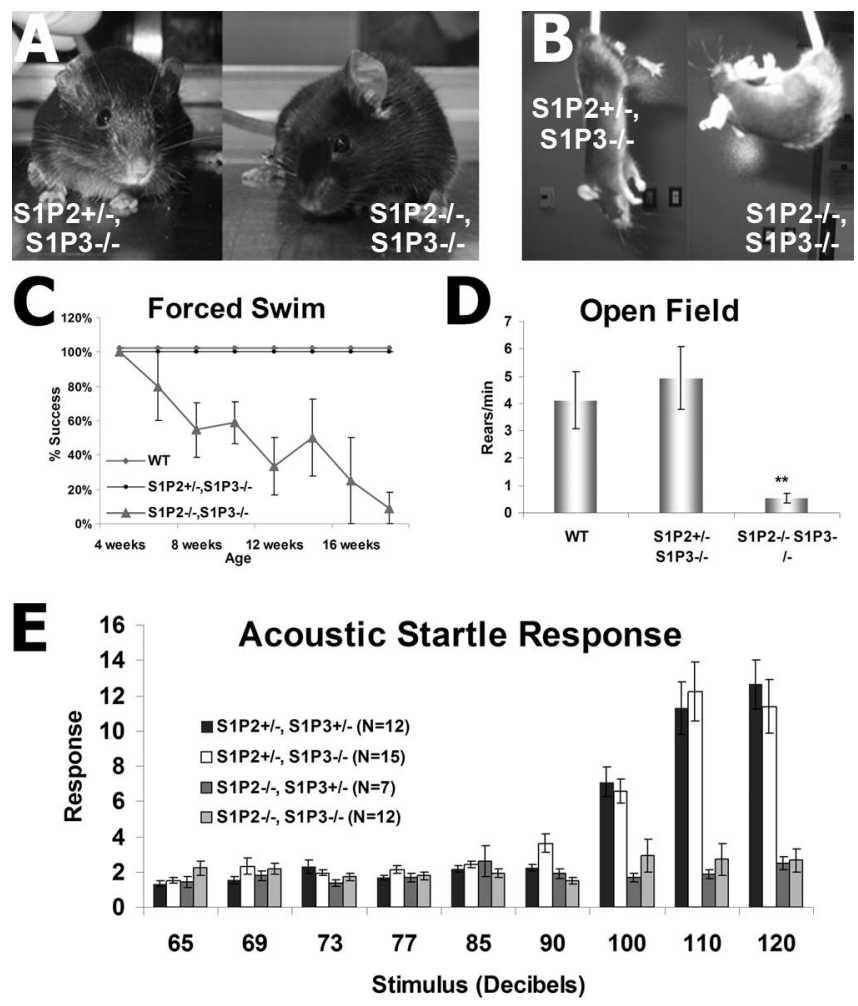

Figure 2. Loss of $S 1 P_{2}$ results in vestibular and cochlear defects. $A, s 1 p_{2} / s 1 p_{3}$ double-null mice display a distinctive head tilt posture characteristic of vestibular lesions. The age of onset varies but is usually detectable before 6 months of age. $\boldsymbol{B}$, When suspended by the tail, wildtype mice will stretch their forelimbs downward toward the ground. Mice with vestibular defects curl upward, often landing on their heads when returned to the ground. $s 1 p_{2} / s 1 p_{3}$ doublenull mice display this behavior, with an age-related increase in penetrance starting at 2 months and occurring uniformly by 6 months of age. C, Wild-type and $s 1 p_{3}{ }^{-1-}$ mice invariably swim for the full $1 \mathrm{~min}$ test period when placed in a beaker of water. $s 1 p_{2} / s 1 p_{3}$ double-null mice fail this test at an increasing frequency with age, with a near-complete penetrance by 18 weeks. $D$, Mice with vestibular defects have difficulty maintaining balance on their hindlimbs and, rather than engaging in normal exploratory behavior by rearing, instead arch their backs to elevate their noses. The marked decrease in rearing frequency noted in these 12 - to 14 -week-old $s 1 p_{2} / s 1 p_{3}$ double-null mice is consistent with vestibular dysfunction (**p $<0.01)$. $E, S 1 P_{2}$ null mice completely lack a detectable response to an acoustic startle stimulus. Heterozygous and $s 7 p_{3}$ null mice respond normally with startle reflex thresholds of $90-100$ decibels. $51 p_{2}$ null mice uniformly fail to respond to even the strongest stimulus from the youngest age tested (4 weeks). Response shown is measured in arbitrary force units. Error bars indicate SD.

\section{$s 1 p_{2}{ }^{-/-} / s 1 p_{3}^{-/-}$mice have progressive loss of}

\section{vestibular function}

As we have reported previously, $s 1 p_{2}$ null and $s 1 p_{2} / s 1 p_{3}$ doublenull mice have no gross anatomical or behavioral differences from their heterozygous or wild-type littermates (Ishii et al., 2002). However, since that report we noted some subtle but consistent postural defects initially in older ( $>6$ months) $s 1 p_{2}{ }^{-/} /$ $s 1 p_{3}{ }^{-/-}$animals. These defects included a persistent head tilt (Fig. 2A) and defects in tail hanging posture (Fig. 2B). Because previous studies have suggested that such posturing is indicative of vestibular defects (Seoane et al., 2001; Paffenholz et al., 2004), we ran these mice through a series of behavioral tests to evaluate dexterity including forced swim, rearing behavior, and contact righting.

The forced swim test is a simple, discrete assay for vestibular function. Mice with significant vestibular lesions are unable to orient themselves spatially in the absence of tactile cues and therefore are unable to swim when placed into a beaker of water. All $s 1 p_{2}{ }^{+/-} / s 1 p_{3}{ }^{+/-}$and $s 1 p_{2}{ }^{+/-} / s 1 p_{3}{ }^{-/-}$animals were able to swim normally at all ages. Similarly, very young $s 1 p_{2}{ }^{-/-} / s 1 p_{3}{ }^{-/-}$ mice (4 weeks) had no difficulty in this assay (Fig. 2C) (supplemental video S2, available at www.jneurosci.org as supplemental material). However, the double-null mice displayed a progressive loss of swimming ability and were almost uniformly deficient by 18 weeks of age. Additionally, $s 1 p_{2}{ }^{-/-} / s 1 p_{3}{ }^{-/-}$mice had a significant reduction in rearing behavior, consistent with an inability to balance on the hindlimbs (Fig. 2D). Double-null mice were also defective in contact righting (supplemental video S3, available at www.jneurosci.org as supplemental material). Differences in body size made quantitation of this assay unreliable, because smaller mice are exposed to additional tactile cues in the righting chamber. However, $s 1 p_{2}{ }^{+/-} / s 1 p_{3}{ }^{-/-}$mice invariably displayed normal righting behavior, but mature $s 1 p_{2}{ }^{-1-} / s 1 p_{3}{ }^{-1-}$ mice always showed significant righting delays.

\section{$\operatorname{slp}_{2}{ }^{-1-}$ mice do not respond to sound}

Given the close relationship between cochlear and vestibular function, we evaluated the double-null mice for their soundevoked sensorimotor response by measuring their acoustic startle response (ASR). Mice heterozygous for $\mathrm{S}_{1} \mathrm{P}_{2}$ exhibited a normal startle reflex, responding to acoustic stimuli $>90-100 \mathrm{~dB}$. This response was the same both in the presence and absence of $\mathrm{S}_{1} \mathrm{P}_{3}$ (Fig. 2E). In contrast, all $s 1 p_{2}{ }^{-/-} / s 1 p_{3}{ }^{+/-}$and $s 1 p_{2}{ }^{-/-} / s 1 p_{3}{ }^{-/-}$ mice completely lacked a startle reflex even at the youngest age that was tested ( 4 weeks).

\section{Hair cells develop normally in $s 1 p_{2}{ }^{-/-} / s 1 p_{3}{ }^{-/-}$mice}

To determine whether the observed behavioral defects were the result of improper hair cell development, we assessed neonatal mice for morphological abnormalities in the inner ear. Examination of hematoxylin and eosin-stained sections showed that both the cochlea and vestibular end organs were normal in appearance until at least $14 \mathrm{~d}$ of age (Fig. $3 A-D$ ). To assess more accurately the morphology of the cochlear hair cells, we labeled wholemount cochlear tissue with FITC-phalloidin to reveal actin-rich stereocilia (Fig. $3 E, F$ ). The overall patterning of the sensory epithelium and the polarity and organization of the stereociliary bundles were indistinguishable between the wild-type and knock-out animals at P4. Furthermore, expression of cadherin 23 $(\mathrm{CDH} 23)$, a marker of differentiating hair cells, was undisturbed in the knock-out mice (Fig. $3 G, H$ ), indicating that the hair cells had undergone normal differentiation (Siemens et al., 2004).

\section{$s 1 p_{2}{ }^{-/-} / s 1 p_{3}{ }^{-/-}$mice have progressive degeneration of inner} ear structures

After a histological examination of older knock-out mice $(>4$ weeks) we observed significant defects in both vestibular end organs and cochleas. Although young mice appeared to be grossly normal, there was profound disorganization of the sensory epithelia of the vestibular maculas in older double-null mice (Fig. $4 A, B)$. We noted a marked decrease of afferent calyces, complete loss of stereocilia, and general disorganization of the epithelial sheet. These defects became pronounced by 4 months of age.

Similarly, structures in the cochlea displayed a progressive, age-dependent increase in severity of the double-null phenotype. Until 2 weeks of age the cochleas appeared to be completely intact. Shortly thereafter, we observed degeneration of the organ of Corti, characterized by loss of inner and outer hair cells and all of their supporting cells (Fig. 4C,D). This degeneration proceeded in a progressive basal-to-apical pattern and was nearly complete by 4 months of age. In addition, there was a striking loss of affer- 

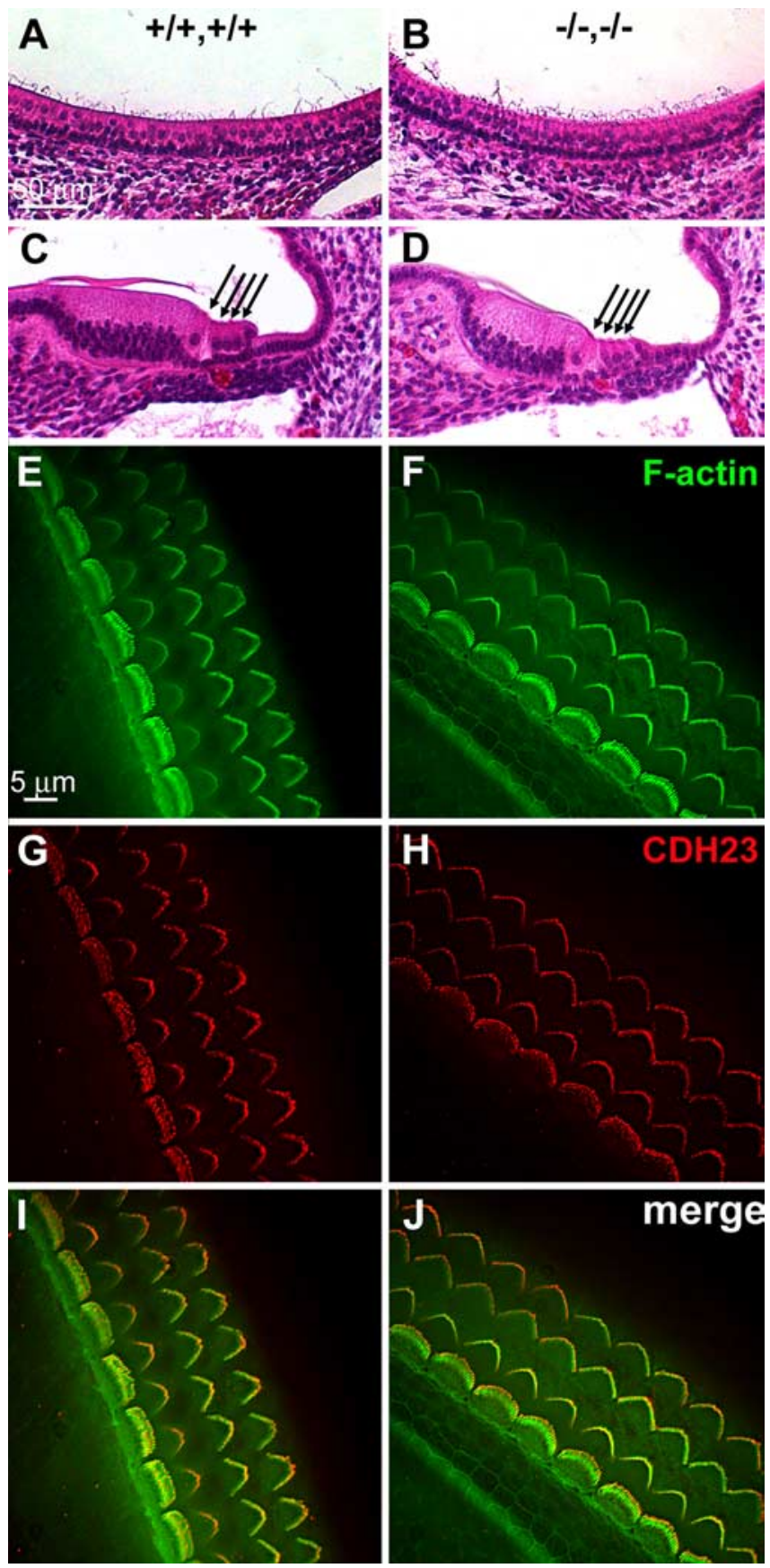

Figure 3. Hair cell development is normal in $s 1 p_{2} / s 1 p_{3}$ double-null mice. $\boldsymbol{A}, \boldsymbol{B}$, Vestibular maculas of wild-type and $s 1 p_{2}{ }^{-1-} / s 1 p_{3}{ }^{-1-}$ mice at $P 1$. The sensory epithelium of the knockout is normal in appearance with normal cell polarity, innervation, and stereociliary projections. C, D, Cochleas of wild-type and $s 1 p_{2}{ }^{-1-} / s 1 p_{3}{ }^{-/-}$mice at P1. All structures of the neonatal cochlea appear to develop normally in the knock-out mouse. Note the presence of one inner and three outer hair cells (arrows) in the developing organ of Corti. Scale bar: (in A) A-D, $50 \mu \mathrm{m}$. E-J, Surface preparation of wild-type and $s 1 p_{2}^{-/-} / s 1 p_{3}{ }^{-/-}$organs of Corti. Tissue was obtained at $\mathrm{P} 4$ from the basal turn of the cochlea, stained with phalloidin to label $\mathrm{F}$-actin in the stereocilia $(\boldsymbol{E}, \boldsymbol{F})$, and stained for $\mathrm{CDH} 23$, a marker for differentiating hair cells $(\boldsymbol{G}, \boldsymbol{H})$. The bottom panels $(I, J)$ show a merge of the two images. Stereociliary bundles appear to be normal in size and morphology in the knock-out animal. Scale bar: (in $E$ ) $E-J, 5 \mu \mathrm{m}$.

ent neurons in the spiral ganglia, with a similar basal-to-apical pattern of degeneration (Fig. $4 E, F$ ).

\section{Discussion}

$\mathrm{S} \mathrm{P}_{2}$ has been shown to mediate a number of diverse responses in a variety of cell types (for review, see Ishii et al., 2004; Gardell et

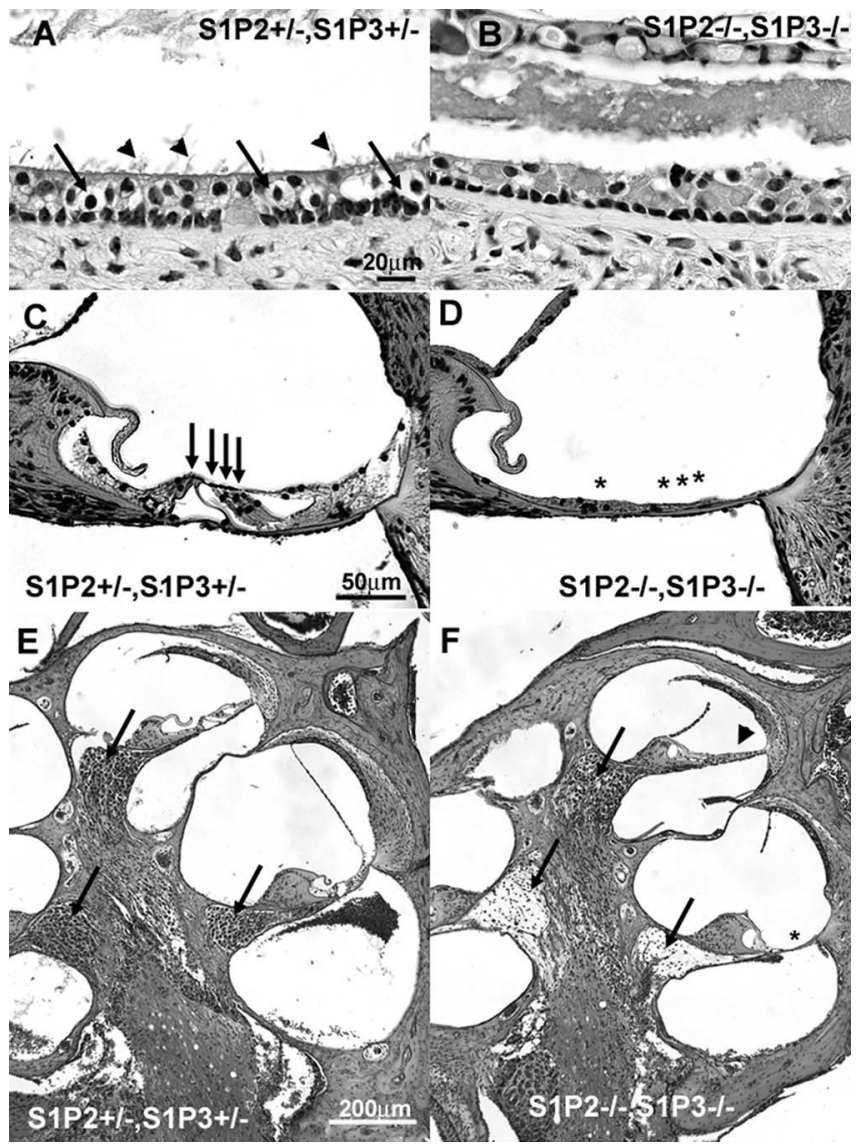

Figure 4. Loss of $S 1 P_{2} / S 1 P_{3}$ causes progressive degeneration of vestibular end organs and cochleas. $A, B$, Vestibular maculas of an 8-month-old $s 1 p_{2}{ }^{-/} / s 1 p_{3}{ }^{-/-}$mouse and heterozygous littermate. The knock-out epithelial layer is markedly disorganized and lacks afferent calyces (arrows) and stereocilia (arrowheads). C, This 2-month-old heterozygous mouse displays normal morphology throughout the length of the organ of Corti. Note the presence of the one inner and three outer hair cells (arrows). D, This $s 1 p_{2}^{-1-} / s 1 p_{3}{ }^{-/-}$littermate bears the characteristic degeneration of the organ of Corti, most strikingly in the basal turn as shown here. Note the absence of all cells of the organ of Corti, including the hair cells $\left(^{*}\right)$. $\boldsymbol{F}$, This image of a 4-month-old cochlea illustrates the characteristic basal-to-apical degeneration seen in our $s 1 p_{2}{ }^{-1-} / s 1 p_{3}{ }^{-1-}$ mice. Note that cells are lost completely in the basal turn (*) (as seen in $\boldsymbol{D}$ ) and are present but disorganized in the apical turns (arrowhead) as compared with similar structures in the heterozygous littermate $(\boldsymbol{E})$. Also note the absence of afferent neurons in the spiral ganglia (arrows) that is coincident with loss of the organ of Corti.

al., 2006), but to date no reports implicate this receptor in cochlear or vestibular function. This study identifies a previously unknown role of $\mathrm{S} \mathrm{P}_{2}$ and adds to a growing list of biological functions mediated by S1P signaling.

Our previous work with $s 1 p_{2}$ null and $s 1 p_{2} / s 1 p_{3}$ double-null mice revealed significant perinatal lethality of $s 1 p_{2}^{-1-}$ pups, but survivors developed into grossly normal adults in a $129 / \mathrm{SvJ}$, C57BL/6N background (Ishii et al., 2002). After backcrossing mice into a pure C57BL/6J (>N6), we occasionally observed mortality in young adults along with rare seizure activity, consistent with reports of an independently generated $s 1 p_{2}$ knock-out line (MacLennan et al., 2001).

Here we report that $s 1 p_{2}{ }^{-1-} / s 1 p_{3}{ }^{-/-}$mice also are characterized by progressive basal-to-apical degeneration of cochlear hair cells, resulting in complete loss of ASR before 4 weeks of age. It is possible that an absence of ASR could be attributable to defects in the CNS or motor function; however, this is unlikely because $s 1 p_{2}{ }^{-1-} / s 1 p_{3}{ }^{-1-}$ mice exhibit normal ambulation and behavior except as noted above. The histological abnormalities described 
here are consistent with profound hearing and vestibular dysfunction. This phenotype is degenerative, rather than developmental, because the fine bundle organization of stereocilia on the top of hair cells is morphologically normal at P4 (Fig. 3I,J) and the cochlear histology appears to be undisturbed until at least 2 weeks of age. In addition, functional and anatomical defects also are found in the closely related hair cells of the vestibular maculas.

The mRNA expression patterns of $\mathrm{S}_{1} \mathrm{P}_{2}$ and $\mathrm{S}_{1} \mathrm{P}_{3}$ suggest indirect mechanisms leading to the loss of sensory hair cells in the knock-out animals. An absence of $\mathrm{S}_{1} \mathrm{P}_{2}$ may result primarily in loss of function of the cochlear-supporting cells that appear to be important for survival of sensory hair cells (Ramirez-Camacho et al., 2004) and afferent neurons (Sugawara et al., 2005). This defect may be exacerbated by compromised normal cochlear blood flow via loss of $\mathrm{S} \mathrm{P}_{3}$ in the vascular bed and/or abnormal glial function. The vascular role of $\mathrm{S}_{3} \mathrm{P}_{3}$ is supported by the observation that S1P may regulate blood flow to the cochlea (Scherer et al., 2006). It is interesting to note that, for both the cochlear and the vestibular systems, additional data (data not shown) suggest that behavioral deficits precede overt hair cell degeneration. This may indicate indirect effects of S1P signaling on hair cell function before the cells degenerate, which may provide a therapeutic window for intervention.

While this manuscript was in preparation, another group described nearly identical vestibular and cochlear phenotypes in an independently generated $s 1 p_{2}$ null mouse in the absence of the ${\mathrm{S} 1 \mathrm{P}_{3}}_{3}$ mutation (MacLennan et al., 2006). Notably, in both cases $s 1 p_{2}{ }^{-1-}$ mice demonstrated profound deafness at the youngest ages that were tested and progressive degeneration of the organ of Corti and spiral ganglia. A major difference between the two lines is penetrance of the vestibular phenotype (43 vs $100 \%$ observed here), likely explained by the concomitant loss of $\mathrm{S}_{1} \mathrm{P}_{3}$, which exacerbates the phenotype.

Overall, these data support the involvement of S1P receptormediated signaling in hair cell function and survival. This finding raises the possibility that selective modulation of $\mathrm{S} 1 \mathrm{P}$ receptors may prevent degeneration associated with exposure to noise or ototoxic drugs such as cisplatin, furosemide, or aminoglycoside antibiotics. A number of compounds with varying specificities for the five known S1P receptors are currently under investigation for other clinical indications and may be applicable to human diseases of cochlear and vestibular origins (Hla, 2004; Gardell et al., 2006).

\section{References}

Anliker B, Chun J (2004) Cell surface receptors in lysophospholipid signaling. Semin Cell Dev Biol 15:457-465.

Gardell SE, Dubin AE, Chun J (2006) Emerging medicinal roles for lysophospholipid signaling. Trends Mol Med 12:65-75.

Grillet N, Dubreuil V, Dufour HD, Brunet J-F (2003) Dynamic expression of RGS4 in the developing nervous system and regulation by the neural type-specific transcription factor Phox2b. J Neurosci 23:10613-10621.

Herr DR, Fyrst H, Phan V, Heinecke K, Georges R, Harris GL, Saba JD (2003) Sply regulation of sphingolipid signaling molecules is essential for Drosophila development. Development 130:2443-2453.

Hla T (2004) Physiological and pathological actions of sphingosine 1-phosphate. Semin Cell Dev Biol 15:513-520.

Ishii I, Contos JJ, Fukushima N, Chun J (2000) Functional comparisons of the lysophosphatidic acid receptors, $\mathrm{LP}_{\mathrm{Al}} / \mathrm{VZG}-1 / \mathrm{EDG}-2, \mathrm{LP}_{\mathrm{A} 2} / \mathrm{EDG}-4$, and $\mathrm{LP}_{\mathrm{A} 3} / \mathrm{EDG}-7$ in neuronal cell lines using a retrovirus expression system. Mol Pharmacol 58:895-902.

Ishii I, Friedman B, Ye X, Kawamura S, McGiffert C, Contos JJ, Kingsbury MA, Zhang G, Brown JH, Chun J (2001) Selective loss of sphingosine 1-phosphate signaling with no obvious phenotypic abnormality in mice lacking its $\mathrm{G}$ protein-coupled receptor, $\mathrm{LP}_{\mathrm{B} 3} / \mathrm{EDG}-3$. J Biol Chem 276:33697-33704.
Ishii I, Ye X, Friedman B, Kawamura S, Contos JJ, Kingsbury MA, Yang AH, Zhang G, Brown JH, Chun J (2002) Marked perinatal lethality and cellular signaling deficits in mice null for the two sphingosine 1-phosphate (S1P) receptors, $\mathrm{S}_{2} \mathrm{P}_{2} / \mathrm{LP}_{\mathrm{B} 2} / \mathrm{EDG}-5$ and $\mathrm{S}_{1} \mathrm{P}_{3} / \mathrm{LP}_{\mathrm{B} 3} / \mathrm{EDG}-3$. J Biol Chem 277:25152-25159.

Ishii I, Fukushima N, Ye X, Chun J (2004) Lysophospholipid receptors: signaling and biology. Annu Rev Biochem 73:321-354.

Kupperman E, An S, Osborne N, Waldron S, Stainier DY (2000) A sphingosine-1-phosphate receptor regulates cell migration during vertebrate heart development. Nature 406:192-195.

Lee CW, Rivera R, Gardell S, Dubin AE, Chun J (2006) GPR92 as a new $\mathrm{G}_{12 / 13^{-}}$and $\mathrm{G}_{\mathrm{q}}$-coupled lysophosphatidic acid receptor that increases cAMP, LPA5. J Biol Chem 281:23589-23597.

Li GC, Foote C, Alexander S, Alexander H (2001) Sphingosine-1-phosphate lyase has a central role in the development of Dictyostelium discoideum. Development 128:3473-3483.

Liu Y, Wada R, Yamashita T, Mi Y, Deng CX, Hobson JP, Rosenfeldt HM, Nava VE, Chae SS, Lee MJ, Liu CH, Hla T, Spiegel S, Proia RL (2000) Edg-1, the G protein-coupled receptor for sphingosine-1-phosphate, is essential for vascular maturation. J Clin Invest 106:951-961.

MacLennan AJ, Carney PR, Zhu WJ, Chaves AH, Garcia J, Grimes JR, Anderson KJ, Roper SN, Lee N (2001) An essential role for the H218/AGR16/ Edg-5/LP $\mathrm{B}_{\mathrm{B} 2}$ sphingosine 1-phosphate receptor in neuronal excitability. Eur J Neurosci 14:203-209.

MacLennan AJ, Benner SJ, Andringa A, Chaves AH, Rosing JL, Vesey R, Karpman AM, Cronier SA, Lee N, Erway LC, Miller ML (2006) The S1P sphingosine 1-phosphate receptor is essential for auditory and vestibular function. Hear Res 220:38-48.

Paffenholz R, Bergstrom RA, Pasutto F, Wabnitz P, Munroe RJ, Jagla W, Heinzmann U, Marquardt A, Bareiss A, Laufs J, Russ A, Stumm G, Schimenti JC, Bergstrom DE (2004) Vestibular defects in head-tilt mice result from mutations in Nox3, encoding an NADPH oxidase. Genes Dev 18:486-491.

Ramirez-Camacho R, Garcia-Berrocal JR, Bujan J, Martin-Marero A, Trinidad A (2004) Supporting cells as a target of cisplatin-induced inner ear damage: therapeutic implications. Laryngoscope 114:533-537.

Risbrough VB, Brodkin JD, Geyer MA (2003) GABA-A and 5-HT1A receptor agonists block expression of fear-potentiated startle in mice. Neuropsychopharmacology 28:654-663.

Roux I, Safieddine S, Nouvian R, Grati M, Simmler MC, Bahloul A, Perfettini I, Le Gall M, Rostaing P, Hamard G, Triller A, Avan P, Moser T, Petit C (2006) Otoferlin, defective in a human deafness form, is essential for exocytosis at the auditory ribbon synapse. Cell 127:277-289.

Saba JD, Hla T (2004) Point-counterpoint of sphingosine 1-phosphate metabolism. Circ Res 94:724-734.

Saba JD, Nara F, Bielawska A, Garrett S, Hannun YA (1997) The BST1 gene of Saccharomyces cerevisiae is the sphingosine-1-phosphate lyase. J Biol Chem 272:26087-26090.

Scherer EQ, Lidington D, Oestreicher E, Arnold W, Pohl U, Bolz SS (2006) Sphingosine-1-phosphate modulates spiral modiolar artery tone: a potential role in vascular-based inner ear pathologies? Cardiovasc Res 70:79-87.

Senften M, Schwander M, Kazmierczak P, Lillo C, Shin JB, Hasson T, Geleoc GS, Gillespie PG, Williams D, Holt JR, MSller U (2006) Physical and functional interaction between protocadherin 15 and myosin VIIa in mechanosensory hair cells. J Neurosci 26:2060-2071.

Seoane A, Dememes D, Llorens J (2001) Pathology of the rat vestibular sensory epithelia during subchronic $3,3^{\prime}$-iminodipropionitrile exposure: hair cells may not be the primary target of toxicity. Acta Neuropathol (Berl) 102:339-348.

Siemens J, Lillo C, Dumont RA, Reynolds A, Williams DS, Gillespie PG, M $\int l l e r ~ U$ (2004) Cadherin 23 is a component of the tip link in hair-cell stereocilia. Nature 428:950-955.

Spiegel S, Milstien S (2003) Sphingosine-1-phosphate: an enigmatic signaling lipid. Nat Rev Mol Cell Biol 4:397-407.

Sugawara M, Corfas G, Liberman MC (2005) Influence of supporting cells on neuronal degeneration after hair cell loss. J Assoc Res Otolaryngol 6:136-147.

Yang AH, Ishii I, Chun J (2002) In vivo roles of lysophospholipid receptors revealed by gene targeting studies in mice. Biochim Biophys Acta 1582: 197-203. 